\title{
PENGARUH LINGKUNGAN KERJA DAN DISIPLIN KERJA TERHADAP KINERJA KARYAWAN PADA PT RESINDO, JAKARTA SELATAN
}

\author{
Sarah Dwi Kusmiyatun*); Sonny \\ Universitas Pamulang \\ *email: sarahdk.2411@gmail.com
}

Paper Accepted: 27 Maret 2021 Paper Reviewed: 28-31 Maret 2021 Paper Edited: 01-15 April 2021 Paper Approved: 26 April 2021

\begin{abstract}
ABSTRAK
Penelitian ini bertujuan untuk mengatahui: 1) Pengaruh lingkungan kerja terhadap kinerja karyawan PT Resindo, Jakarta Selatan, 2) Pengaruh disiplin kerja terhadap kinerja karyawan PT Resindo, Jakarta Selatan, 3) Pengaruh lingkungan kerja dan disiplin kerja terhadap kinerja karyawan pada PT Resindo, Jakarta Selatan. Penelitian ini menggunakan metode kuantitaif dengan sampel penelitian ini adalah 55 orang yang seluruhnya adalah karyawan PT Resindo, Jakarta Selatan. Pengumpulan data menggunakan kuesioner yang telah diuji validitas dan realibilitasnya. Hasil penelitian menemukan bahwa: 1) Lingkungan kerja berpengaruh positif dan signifikan terhadap kinerja karyawan pada PT Resindo, Jakarta Selatan. 2) Disiplin kerja berpengaruh positif dan signifikan terhadap Kinerja karyawan pada PT Resindo, Jakarta Selatan. 3) Lingkungan kerja dan disiplin kerja memiliki pengaruh positif dan slimutan terhadap kinerja karyawan pada PT Resindo, Jakarta Selatan.
\end{abstract}

Kata Kunci: Lingkungan Kerja, Disiplin Kerja, Kinerja Karyawan

\section{PENDAHULUAN}

\section{Latar Belakang}

Keberhasilan suatu perusahaan tidak selalu diukur oleh seberapa besar uang yang dimiliki melainkan ada hal lain yang lebih penting yaitu Sumber Daya Manusia (SDM) yang berada di perusahaan. Semakin baik kualitas karyawan suatu perusahaan maka semakin tinggi daya saing perusahaan tersebut terhadap perusahaan lainnya. Karyawan adalah aset berharga yang perlu diperhatikan dan dibina dengan baik sehingga perusahaan harus memperhatikan setiap detil program-program yang berkaitan dengan pengembangan sumber daya manusia guna menghasilkan karyawan yang kompeten dan berdaya saing tinggi.

Sumber daya manusia merupakan salah satu unsur dari organisasi dan memiliki peran yang penting dalam kegiatan organisasi (Notoatmojo, 2012). Manusia sebagai salah satu komponen organisasi merupakan Sumber Daya penentu tercapainya visi dan misi organisasi.
Sehinga SDM harus dikelola sedemikian rupa sehingga berdaya guna dalam mencapai misi dan tujuan. SDM sangat bepengaruh terhadap kualitas tenaga kerja yang tepat, untuk mengisi barbagai kedudukan, jabatan, masa kerja, kepangkatan dan sebagainya untuk mencapai tujuan organisansi.

Pada prosesnya prestasi perusahaan ataupun kinerja perusahaan mengalami pasang surut sejalan dengan naik turunnya Kinerja karyawan perusahaan itu sendiri. Hal ini menandakan bahwa ada hubungan yang positif antara karyawan perusahaan dengan perusahaan tempat mereka bekerja. Kinerja adalah hasilhasil fungsi pekerjaan seseorang atau kelompok dalam suatu organisasi pada periode waktu tertentu yang merefleksikan seberapa baik seseorang atau kelompok tersebut memenuhi persyaratan sebuah pekerjaan dalam usaha pencapaian tujuan organisasi (Bernardin \& Russel, 2013).

Menurut Putri (2020) dalam jurnal penelitiannya, salah satu faktor yang 
mempengaruhi kinerja karyawan ialah lingkungan kerja. Lingkungan kerja merupakan segala sesuatu yang ada di sekitar para pekerja yang dapat mempengaruhi dirinya dalam melaksanakan tugas-tugas yang dibebankan. Lingkungan kerja dalam suatu instansi sangat penting sehingga masuk kedalam hal yang harus diperhatikan oleh manajemen, karena lingkungan kerja merupakan sauna dimana karyawan melakukan aktivitas setiap hari.

Lingkungan kerja yang kondusif memberikan rasa aman dan memungkinkan karyawan untuk dapat bekerja secara optimal.
Jika karyawan sangat nyaman akan lingkungan kerja, maka karyawan tersebut akan merasa aman dan nyaman dalam melakukan pekerjaannya sehingga munculah sikap disiplin kerja. Sebaliknya, jika lingkungan kerja yang tidak memadai maka dapat menurunkan produktvitas kerja karyawan. Lingkungan kerja adalah segala sesuatu yang ada di sekitar karyawan dan dapat mempengaruhi dalam menjalankan tugas yang diberikan kepadanya misalnya dengan adanya air conditioner (AC), penerangan yang memadai dan sebagainya (Nitisemito, 2013).

\begin{tabular}{|c|c|c|c|}
\hline No. & $\begin{array}{c}\text { Jenis Sarana } \\
\text { Prasarana }\end{array}$ & Kondisi di Perusahaan & Standar Sarana dan Prasarana* \\
\hline 1 & Meja Kerja & $\begin{array}{lrr}\text { Peletakan } & \text { CPU } & \text { berada } \\
\text { dibawah } & \text { meja } & \text { tepat } \\
\text { didepan kaki karyawan } & \text { kawgang } \\
\text { sehingga } & \text { mengganggu } \\
\text { pergerakan kaki. }\end{array}$ & $\begin{array}{l}\text {-Tidak boleh ada CPU/dokumen } \\
\text { yang diletakan dibawah meja } \\
\text { sehingga dapat mengganggu } \\
\text { pergerakan kaki. }\end{array}$ \\
\hline 2 & $\mathrm{AC}$ & $\begin{array}{ll}- & \text { Lantai } 1 \text { (satu) } 22^{\circ} \mathrm{C} \\
\text { - } & \text { Lantai } 2 \text { (dua) } 22^{\circ} \mathrm{C} \\
\text { - } & \text { Lantai } 3 \text { (tiga) } 25^{\circ} \mathrm{C} \\
- & \text { Lantai } 4 \text { (empat) } 25^{\circ} \mathrm{C} \\
\end{array}$ & $23^{\circ}-26^{\circ} \mathrm{C}$ \\
\hline 3 & Kursi Kerja & 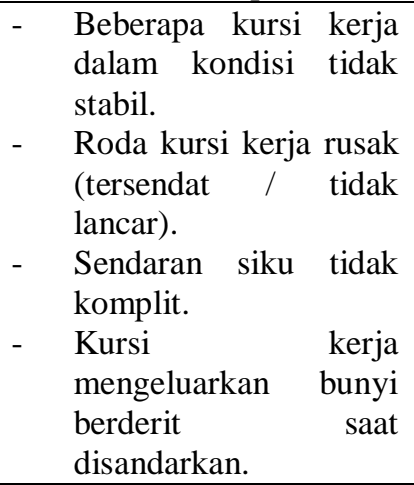 & $\begin{array}{l}\text {-Kursi harus stabil. } \\
\text {-Memiliki } 5 \text { kaki, baik beroda } \\
\text { maupun tidak beroda. }\end{array}$ \\
\hline 4 & Toilet & $\begin{array}{llr}\text { - } & \text { Toilet } & \text { karyawan } \\
\text { wanita } & \text { maupun } \\
\text { karyawan } & \text { pria } \\
\text { dicampur. } & \\
\text { Kondisi } & \text { kebersihan } \\
\text { toilet yang } \quad \text { kurang } \\
\text { dijaga. }\end{array}$ & $\begin{array}{l}\text {-Toilet karyawan wanita terpisah } \\
\text { dengan toilet untuk karyawan } \\
\text { pria. } \\
\text {-Rasio jumlah toilet dan petursan } \\
\text { dengan jumlah tenaga kerja. } \\
\text { (pria = } 1: 40 \text { dan wanita = } \\
1: 25)\end{array}$ \\
\hline 5 & Tikus kecil & $\begin{array}{l}\text { Pada tahun } 2019 \text { telah } \\
\text { dilakukan penangkapan } \\
\text { tikus dengan lem tikus } \\
\text { sebanyak } 3 \text { kali. }\end{array}$ & 0 (tidak ada) \\
\hline 6 & Ventilasi & $\begin{array}{l}\text { Tidak ada ventilasi hanya } \\
\text { ada exhaust. }\end{array}$ & $\begin{array}{l}\text {-Ruang kerja } 0,57 \mathrm{~m} 3 / \mathrm{org} / \mathrm{min} \\
\text {-Ruang pertemuan } 1,05 \\
\text { m3/org/min }\end{array}$ \\
\hline
\end{tabular}

Tabel 1. Hasil observasi sarana dan prasarana PT Resindo

Sumber: PT Resindo data (2020) *Permenkes Nomor 48 Tahun 2016. 
Berdasarkan tabel 1, diketahui bahwa sarana prasarana kerja pada PT Resindo belum melakukan penerapaan yang sesuai dengan Peraturan Menteri Kesehatan Nomor 48 Tahun 2016. Hal ini perlu diperhatikan oleh manajemen PT Resindo, sebab hal ini dapat meningkatkan niat bekerja, konsentrasi karyawan serta karyawan dapat dengan nyaman bekerja sehingga dapat meningkatkan kinerja terhadap perusahaan kedepannya. Selain faktor lingkungan kerja, faktor lain yang mempengaruhi Kinerja karyawan ialah kedisiplinan yang dimiliki oleh setiap karyawan (Putri, 2020). Kedisiplinan merupakan fungsi manajemen sumber daya manusia (MSDM) yang terpenting dan kunci terwujudnya tujuan karena tanpa disiplin yang baik sulit terwujudnya tujuan yang maksimal (Hasibuan, 2013).

\begin{tabular}{|c|c|c|c|c|c|c|c|c|c|c|}
\hline \multirow[b]{2}{*}{ No } & \multirow[b]{2}{*}{ Bulan } & \multicolumn{3}{|c|}{2017} & \multicolumn{3}{|c|}{2018} & \multicolumn{3}{|c|}{2019} \\
\hline & & $\begin{array}{c}\text { Total } \\
\text { Karyawan }\end{array}$ & \begin{tabular}{|c|} 
Kasus \\
Karyawan \\
Terlambat
\end{tabular} & $\begin{array}{c}\text { Presentase } \\
\text { Keterlambatan }\end{array}$ & $\begin{array}{c}\text { Total } \\
\text { Karyawan }\end{array}$ & \begin{tabular}{|c|} 
Kasus \\
Karyawan \\
Terlambat \\
\end{tabular} & $\begin{array}{c}\text { Presentase } \\
\text { Keterlambatan }\end{array}$ & $\begin{array}{c}\text { Total } \\
\text { Karyawan }\end{array}$ & \begin{tabular}{|c|} 
Kasus \\
Karyawan \\
Terlambat \\
\end{tabular} & $\begin{array}{c}\text { Presentase } \\
\text { Keterlambatan }\end{array}$ \\
\hline 1 & Jan & 34 & 10 & $1 \%$ & 42 & 10 & $1 \%$ & 58 & 9 & $1 \%$ \\
\hline 2 & Feb & 34 & 12 & $2 \%$ & 42 & 9 & $1 \%$ & 58 & 6 & $0 \%$ \\
\hline 3 & Mar & 34 & 10 & $1 \%$ & 42 & 10 & $1 \%$ & 58 & 6 & $0 \%$ \\
\hline 4 & Apr & 34 & 9 & $1 \%$ & 42 & 10 & $1 \%$ & 58 & 7 & $1 \%$ \\
\hline 5 & May & 34 & 12 & $2 \%$ & 42 & 10 & $1 \%$ & 58 & 10 & $1 \%$ \\
\hline 6 & Jun & 34 & 15 & $2 \%$ & 42 & 16 & $2 \%$ & 58 & 10 & $1 \%$ \\
\hline 7 & Jul & 34 & 10 & $1 \%$ & 42 & 10 & $1 \%$ & 58 & 7 & $1 \%$ \\
\hline 8 & $\mathrm{Agu}$ & 34 & 14 & $2 \%$ & 42 & 12 & $1 \%$ & 58 & 8 & $1 \%$ \\
\hline 9 & Sep & 34 & 9 & $1 \%$ & 42 & 15 & $2 \%$ & 58 & 10 & $1 \%$ \\
\hline 10 & Okt & 34 & 9 & $1 \%$ & 42 & 10 & $1 \%$ & 58 & 6 & $0 \%$ \\
\hline 11 & Nov & 34 & 10 & $1 \%$ & 42 & 10 & $1 \%$ & 58 & 7 & $1 \%$ \\
\hline 12 & Des & 34 & 12 & $2 \%$ & 42 & 11 & $1 \%$ & 58 & 9 & $1 \%$ \\
\hline \multicolumn{2}{|c|}{ Total } & \multicolumn{3}{|c|}{$1,5 \%$} & \multicolumn{3}{|c|}{$1,2 \%$} & \multicolumn{3}{|c|}{$0,6 \%$} \\
\hline \multicolumn{2}{|c|}{$\begin{array}{l}\text { Rata-rata } \\
\text { Keterlambatan } \\
\text { per bulan }\end{array}$} & \multicolumn{3}{|c|}{11} & \multicolumn{3}{|c|}{11,1} & \multicolumn{3}{|c|}{7,9} \\
\hline
\end{tabular}

Tabel 2. Rekapitulasi keterlambatan karyawan. Sumber: PT Resindo data (2020)

Dari tabel 2 menunjukan bahwa masih terdapat karyawan yang terlambat masuk kerja artinya bahwa kedisiplinan kerja di PT Resindo masih belum diterapkan secara baik. Padahal peraturan perusahaan menargetkan keterlambatan $0 \%$ per tahunnya. Hal ini akan berakibat pada hasil pekerjaan yang kurang maksimal karena diselesaikan dengan hanya menggunakan sisa waktu akibat keterlambatan datang. Kinerja karyawan PT Resindo dinilai dari banyaknya proyek yang telah diselesaikan dalam waktu yang telah ditentukan serta tidak adanya kemunduran waktu akan penyelesaian pekerjaan. Jika terjadinya kemunduran waktu penyelesaian maka akan berakibat pada terlambatnya pula pembayaran klien atas pekerjaan proyek tersebut.

\begin{tabular}{|c|c|c|c|c|c|}
\hline Tahun & $\begin{array}{c}\text { Jumlah } \\
\text { Karyawan } \\
\text { (Orang) }\end{array}$ & $\begin{array}{c}\text { Jumlah } \\
\text { Proyek }\end{array}$ & $\begin{array}{c}\text { Jumlah Proyek } \\
\text { Terselesaikan }\end{array}$ & $\begin{array}{c}\text { Proyek } \\
\text { Terselesaikan } \\
(\%)\end{array}$ & $\begin{array}{c}\text { Est. Kebutuhan } \\
\text { Karyawan Per } \\
\text { Proyek }\end{array}$ \\
\hline 2017 & 34 & 7 & 6 & $80 \%$ & 29 \\
\hline 2018 & 42 & 8 & 6 & $75 \%$ & 32 \\
\hline 2019 & 58 & 10 & 6 & $60 \%$ & 35 \\
\hline
\end{tabular}

Tabel 3. Data proyek PT Resindo. Sumber: PT Resindo internal data (2020)

Dari tabel 3 dapat dilihat bahwa dalam jumlah proyek yang didapat setiap tahunnya belum bisa terselesaikan dengan sempurna.
Padahal jumah karyawan dalam kurun 3 tahun bertambah. Hal ini menjadikan pengerjaan proyek menjadi kurang efektif. Misalkan pada 
tahun 2017, 29 orang dapat menyelesaikan 1 proyek. Namun di tahun 2019 membutuhkan 35 orang hanya untuk satu proyek. Sehingga presentase proyek yang terselesaikan menjadi menurun. Dilihat dari data di atas tergambar bahwa tingkat kedisiplinan karyawan berdasarkan hari kerja efektif dan jumlah karyawan sebagai salah satu instrumen pelaksanaan disiplin termasuk dalam kategori kurang disiplin.

Berdasarkan permasalahan di atas peneliti tertarik untuk melakukan penelitian mengenai "Pengaruh Lingkungan Kerja dan Disiplin Kerja Terhadap Kinerja Karyawan Pada PT Resindo, Jakarta Selatan".

\section{Rumusan Masalah}

Berdasarkan latar belakang masalah yang diuraikan di atas, maka peneliti merumuskan masalah sebagai berikut: 1. Apakah terdapat pengaruh lingkungan kerja terhadap kinerja karyawan PT Resindo, 2. Apakah terdapat pengaruh disiplin kerja terhadap kinerja karyawan PT Resindo, 3. Apakah terdapat pengaruh lingkungan kerja dan disiplin kerja terhadap kinerja karyawan PT Resindo.

\section{METODE PENELITIAN}

Jenis penelitian ini ialah penelitian asosiatif, menurut Sugiyono (2017:44) yaitu "penelitian yang bertujuan untuk mengetahui pengaruh atau hubungan antara dua variabel atau lebih". Dengan demikian penelitian asosiatif ini dapat dibangun suatu teori yang berfungsi untuk menjelaskan, meramalkan dan mengontrol suatu gejala. Penelitian ini merupakan studi empiris yang bertujuan untuk menguji pengaruh lingkungan kerja dan disiplin kerja terhadap Kinerja karyawan. Obyek penelitian ini dilakukan pada PT Resindo yang beralamat di Jl. Ciputat Raya no. 1B unit 1\&2, Pondok Pinang, Kebayoran Lama, Jakarta Selatan. Waktu penelitian dilakukan selama 5 (lima) bulan yang dilaksanakan pada awal bulan Juni - Oktober 2020.

Populasi adalah wilayah generalisasi yang terdiri atas objek atau subjek yang mempunyai kuantitas dan karateristik tertentu yang ditetapkan peneliti untuk dipelajari dan kemudian ditarik kesimpulan (Sugiyono, 2017:80). Dalam penelitian ini populasi sebanyak 55 adalah karyawan di PT Resindo. Sampel adalah sebagian dari karateristik yang dimiliki oleh populasi yang menjadi sumber data sebenarnya dalam suatu penelitian (Sugiyono,2017:80). Menurut Arikunto (2011:104) jika jumlah populasinya kurang dari 100 orang, maka jumlah sampelnya diambil secara keseluruhan, tetapi jika populasinya lebig besar dari 100 orang, maka bisa diambil $10-$ $15 \%$ atau $20-25 \%$ dari jumlah populasinya.

Adapun penentuan jumlah sampel yang digunakan oleh peneliti dalam penelitian ini adalah dengan metode sensus berdasarkan pada ketentuan yang dikemukakan oleh Sugiyono (2017:81), yang mengatakan bahwa "Sampling jenuh adalah teknik penentuan sampel bila semua anggota populasi digunakan sebagai sampel. Istilah lain dari sampel jenuh ialah sensus". Sampel yang digunakan pada penelitian ini adalah karyawan PT Resindo yaitu sebanyak 55 orang karyawan. Dalam penelitian ini, peneliti mengumpulkan daya menggunakan teknik sebagai berikut:

Data yang digunakan dalam penelitian ini adalah data primer. Menurut (Sugiyono,2011:137), "Sumber data penelitian yang diperoleh secara langsung dari sumber asli memberikan data kepada pengumpul data. Data primer yang peneliti gunakan sebagai berikut: Observasi adalah pengamatan dan pencatatan secara terliti dan sistematis dari gejala - gejala yang sedang diteliti. Menurut Sugiyono (2017:141) berpendapat "observasi adalah proses yang tersusun dari berbagai proses sehingga diperoleh data berdasarkan fakta mengenai dunia kenyataan yang diperoleh melalui observasi". Pada penelitian ini peneliti melaksanakan pengatan yang mana pengamatan pada PT Resindo terbatas sehingga penelitian dapat lebih fokus pada data dan relevan. Kuesioner adalah daftar pernyataan tertulis yang digunakan untuk memperoleh informasi dari responden. Kuisioner yang dibuat yaitu mengenai Pengaruh Lingkungan Kerja dan Disiplin Kerja Terhadap Kinerja Karyawan pada PT Resindo. Dalam penelitian ini kuesioner yang dibuat berupa pernyataan dengan jawaban mengacu pada skala likert: Sangat Tidak Setuju (bobot 1), Tidak Setuju (bobot 2), Kurang Setuju (bobot 3), Setuju (bobot 4) dan Sangat Setuju (bobot 5).

Data sekunder merupakan sumber data yang tidak dapat langsung memeberikan data kepada pengumpulan data, misalnya melalui orang lain atau melalui dokumen, Sugiyono (2011:137). Adapun data sekunder yang peneliti gunakan yaitu: Studi Kepustakaan (Library Research). Dengan mempelajari, meneliti dan mengkaji serta menelaah buku literature, jurnal, penelitian terdahulu, catatan historis (data dokumen) yang dipublikasikan guna 
memperoleh data sekunder yang akan dijadikan landasan teori yang berkaitan langsung dengan kinerja karyawan.

Metode analisis yang digunkan dalam penelitian ini adalah analisis deskriptif kuantitatif. Metode ini bertujuan untuk menggambarkan sifat sesuatu yang tengah berlangsung pada saat riset dilakukan dan menerima sebab - sebab dari suatu gejala tertentu, Sugiyono (2017:147). Tahap dalam melaksanakan kegiatan penelitian ini diawali dengan menganalisi data yang digunakan dalm penelitian, serta diikuti dengan pengujian terhadap hipotesis penelitian. Analisis data merupakan penyederhanaan data ke dalam bentuk yang mudah dipahami, dibaca dan di interpesentasikan. Data yang akan dianalisis merupakan data hasil penelitian lapangan dan penelitian kepustakaan, serta diikuti dengan pengujian terhadap hipotesis penelitian, kemudian penelitian melakukan analisis untuk menarik kesimpulan. Untuk mendapatkan data yang diperoleh bagi pencapaian sasaran penelitian ini maka digunakan pengukuran melalui kuesioner. Teknik analisis data ini menggunakan SPSS V26.

\section{PEMBAHASAN}

PT Resindo merupakan Perusahaan jasa konsultan, EPCM dan EPC yang berbasis di Indonesia dan beroperasi selama 7 tahun. PT Resindo terdiri dari Personil Domestik dan Personil International dengan latar belakang yang kuat pada sektor Mineral, Pembangkit Listrik serta Minyak Bumi dan Gas. Perusahaan ini memperoleh status badan hukum menjadi PT atau Perseroan Terbatas pada tahun 2013 berdasarkan TDP (Tanda Daftar Perusahaan) dengan no. 09.03.1.71.82723, nomor Surat Pengesahan AHU-11463.AH.01.01.Tahun 2013 oleh Menteri Hukum dan Hak Asasi Manusia, no. Persetujuan Menteri Hukum dan HAM atas Akte Perubahan Anggaran Dasar AHU32508.AH.01.02. Tahun 2013 dan AHU06632.AH.01.02.Tahun 2014 dan memiliki NPWP dengan nomor 03.280.546.7-017.000 . Kantor PT Resindo berlokasi di Jl. Ciputat Raya no.1B unit 1 \& 2, Kel. Pondok Pinang, Kec. Kebayoran Lama, Jakarta Selatan. Sejak tahun 2013 hingga sekarang PT Resindo telah mengikuti lebih dari 20 proyek yang tersebar di seluruh wilayah Indonesia, yang terdiri dari proyek analisis Studi Kelayakan, Process \& Engineering Design (DED), Dragting Services, EPCM \& EPC Service and Capital \& Operational Cost Development Review.

Visi PT Resindo ialah menjadi Perusahaan yang menyediakan pelayanan Consultant dan Construction Engineering yang secara langsung ke klient atau sebagai Third Party. Sedangkan misinya melakukan berbagai kerjasama dengan klient dan menyelaraskan team Resindo untuk dapat bekerjasama dalam memenuhi tujuan proyek baik dalam hal biaya, K3 serta jadwal penyelesaian proyek. Kemudian mengembangkan tenaga kerja lokal dengan keterampilan, kompetensi dan kinerja yang unggul dan sebagai badan usaha dengan bisnis inti rancangan bangunan fasilitas pertambangan minyak bumi dan gas serta bidang terkaitnya.

\section{Uji Validitas}

\begin{tabular}{|l|l|l|l|}
\hline No. & $\begin{array}{l}\mathbf{r} \\
\text { hitung }\end{array}$ & $\begin{array}{l}\mathbf{r} \\
\text { tabel } \\
\mathbf{5 \%}\end{array}$ & Keterangan \\
\hline 1 & 0,795 & 0,266 & Valid \\
\hline 2 & 0,724 & 0,266 & Valid \\
\hline 3 & 0,315 & 0,266 & Valid \\
\hline 4 & 0,567 & 0,266 & Valid \\
\hline 5 & 0,280 & 0,266 & Valid \\
\hline 6 & 0,666 & 0,266 & Valid \\
\hline 7 & 0,730 & 0,266 & Valid \\
\hline 8 & 0,720 & 0,266 & Valid \\
\hline
\end{tabular}




\begin{tabular}{|l|l|l|l|}
9 & 0,729 & 0,266 & Valid \\
\hline 10 & 0,350 & 0,266 & Valid \\
\hline
\end{tabular}

Tabel 4. Hasil uji validitas variabel X1 (lingkungan kerja). Sumber: Hasil Olah Data SPSS V26

Berdasarkan tabel 4, dapat disimpulkan bahwa semua butir pertanyaan dengan jumlah 55 responden dikatakan valid. Hal ini dikarenakan r-hitung > r-tabel dengan menggunakan taraf signifikan 0,05 atau lima persen.

\begin{tabular}{|c|c|c|c|}
\hline No. & $\begin{array}{c}\mathbf{r} \\
\text { hitung }\end{array}$ & $\begin{array}{c}\mathbf{r} \\
\text { tabel } \\
\mathbf{5 \%}\end{array}$ & Keterangan \\
\hline 1 & 0,604 & 0,266 & Valid \\
\hline 2 & 0,611 & 0,266 & Valid \\
\hline 3 & 0,649 & 0,266 & Valid \\
\hline 4 & 0,635 & 0,266 & Valid \\
\hline 5 & 0,274 & 0,266 & Valid \\
\hline 6 & 0,527 & 0,266 & Valid \\
\hline 7 & 0,612 & 0,266 & Valid \\
\hline 8 & 0,428 & 0,266 & Valid \\
\hline 9 & 0,463 & 0,266 & Valid \\
\hline 10 & 0,474 & 0,266 & Valid \\
\hline
\end{tabular}

Tabel 5. Hasil uji validitas variabel X2 (disiplin kerja).

Sumber: Hasil Olah Data SPSS V26

Berdasarkan tabel 5 dijelaskan bahwa semua butir pertanyaan dengan jumlah 55 responden dikatakan valid, hal ini dikarenakan r-hitung > r-tabel dengan menggunakan taraf 0,05 atau lima persen.

\begin{tabular}{|c|c|c|c|}
\hline No. & r hitung & $\boldsymbol{r}$ tabel 5\% & Keterangan \\
\hline 1 & 0,274 & 0,266 & Valid \\
\hline 2 & 0,529 & 0,266 & Valid \\
\hline 3 & 0,653 & 0,266 & Valid \\
\hline 4 & 0,786 & 0,266 & Valid \\
\hline 5 & 0,599 & 0,266 & Valid \\
\hline 6 & 0,771 & 0,266 & Valid \\
\hline 7 & 0,694 & 0,266 & Valid \\
\hline 8 & 0,609 & 0,266 & Valid \\
\hline 9 & 0,630 & 0,266 & Valid \\
\hline 10 & 0,590 & 0,266 & Valid \\
\hline
\end{tabular}

Tabel 6. Hasil uji validitas variabel Y (kinerja karyawan).

Sumber: Hasil Olah Data SPSS V26 
Berdasarkan tabel 6, dapat disimpulkan bahwa semua butir pertanyaan dengan jumlah 55 responden dikatakan valid, hal ini dikarenakan r-hitung > r-tabel dengan menggunakan taraf signifikan 0,05 atau lima persen.

\section{Uji Reliabilitas}

Uji reliabilitas bertujuan untuk melihat apakah kuisioner memiliki konsistensi jika pengukuran dilakukan dengan kuisioner tersebut secara berulang. Dengan ketentuan apabila nilai Cronbach's Alpha > 0,6 maka kuisioner dinyatakan reliabel. Begitupun sebaliknya jika nilai Cronbach's Alpha < 0,6 maka kuisioner dinyatakan tidak reliabel.

\begin{tabular}{|c|l|c|c|c|}
\hline No. & \multicolumn{1}{|c|}{ Variabel } & $\begin{array}{c}\text { Cronbach's } \\
\text { Alpha }\end{array}$ & $\begin{array}{c}\text { Standar } \\
\text { Cronbach's } \\
\text { Alpha }\end{array}$ & Keterangan \\
\hline 1 & Lingkungan Kerja (X1) & 0,813 & 0,60 & Reliabel \\
\hline 2 & Disiplin Kerja (X2) & 0,674 & 0,60 & Reliabel \\
\hline 3 & Kinerja Karyawan (Y) & 0,784 & 0,60 & Reliabel \\
\hline
\end{tabular}

Tabel 7. Hasil uji reliabilitas Sumber: Hasil Olah Data SPSS V26

Berdasarkan tabel 7, diketahui bahwa nilai Cronbach's Alpha, pada variabel lingkungan kerja (X1), disiplin kerja (X2) dan kinerja karyawan (Y) memiliki nilai yang lebih besar dari 0,60. Maka dapat disimpulkan bahwa pernyataan kuisioner untuk setiap variabel adalah reliabel atau konsisten.

\section{Uji Koefisien Korelasi}

\begin{tabular}{|c|c|c|c|}
\hline \multicolumn{4}{|c|}{ Correlations } \\
\hline & & $\begin{array}{l}\text { Lingkungan } \\
\text { Kerja (X1) }\end{array}$ & $\begin{array}{c}\text { Kinerja } \\
\text { Kerja (Y) }\end{array}$ \\
\hline \multirow[t]{3}{*}{$\begin{array}{l}\text { Lingkungan } \\
\text { Kerja (X1) }\end{array}$} & Pearson Correlation & 1 & $.431^{* *}$ \\
\hline & Sig. (2-tailed) & & 0,001 \\
\hline & $\mathrm{N}$ & 55 & 55 \\
\hline \multirow{3}{*}{$\begin{array}{l}\text { Kinerja Kerja } \\
(\mathrm{Y})\end{array}$} & Pearson Correlation & $.431^{* *}$ & 1 \\
\hline & Sig. (2-tailed) & 0,001 & \\
\hline & $\mathrm{N}$ & 55 & 55 \\
\hline
\end{tabular}

**. Correlation is significant at the 0.01 level (2-tailed).

Tabel 8. Hasil uji koefisien korelasi lingkungan kerja (X1) terhadap kinerja karyawan (Y). Sumber: Hasil Olah Data SPSS V26

Dari tabel 8 dapat disimpulkan bahwa lingkungan kerja (X1) dan kinerja karyawan (Y) memiliki hubugan dengan derajat sedang sebesar 0,431 . 


\begin{tabular}{|llr|r|}
\hline & \multicolumn{1}{|c|}{ Correlations } & \multicolumn{1}{c|}{$\begin{array}{c}\text { Disiplin } \\
\text { Kerja (X2) }\end{array}$} & \multicolumn{1}{c|}{$\begin{array}{c}\text { Kinerja } \\
\text { Kerja (Y) }\end{array}$} \\
\hline $\begin{array}{l}\text { Disiplin Kerja } \\
\text { (X2) }\end{array}$ & Pearson Correlation & 1 & $.477^{* * *}$ \\
& Sig. (2-tailed) & & 0,000 \\
\hline Kinerja Kerja & Pearson Correlation & $.477^{* *}$ & 1 \\
(Y) & Sig. (2-tailed) & 0,000 & \\
& N & 55 & 55 \\
\hline
\end{tabular}

**. Correlation is significant at the 0.01 level (2-tailed).

Tabel 9. Hasil uji koefisien korelasi disiplin kerja (X2) terhadap kinerja karyawan (Y). Sumber: Hasil Olah Data SPSS V26

Dari table 9, dapat disimpulkan bahwa disiplin kerja (X2) dan kinerja karyawan (Y) memiliki hubungan korelasi dengan derajat hubungan sedang sebesar 0,477.

\section{Analisis Regresi Sederhana dan Regresi Berganda}

Analisis regresi sederhana digunakan untuk melihat bagaimana pengaruh variabel bebas terhadap variabel terkait.

\begin{tabular}{|c|c|c|c|c|c|c|}
\hline \multicolumn{7}{|c|}{ Coefficients $^{\mathrm{a}}$} \\
\hline \multirow{2}{*}{\multicolumn{4}{|c|}{ Model }} & \multirow{3}{*}{$\begin{array}{c}\text { Standardized } \\
\text { Coefficients } \\
\text { Beta } \\
\end{array}$} & & \multirow[b]{2}{*}{ Sig. } \\
\hline & & & & & & \\
\hline 1 & (Constant) & 26,000 & 4,341 & & 5,990 & 0,000 \\
\hline & $\begin{array}{l}\text { Lingkungan } \\
\text { Kerja (X1) }\end{array}$ & 0,381 & 0,110 & 0,431 & 3,482 & 0,001 \\
\hline
\end{tabular}

a. Dependent Variable: Kinerja Kerja (Y)

Tabel 10. Hasil uji regresi sederhana lingkungan kerja (XI) terhadap kinerja karyawan (Y). Sumber: Hasil Olah Data SPSS V26

Berdasarkan tabel 10, hasil penghitungan output di atas menunjukkan bahwa koefisien dari hasil persamaan regresi dapat diinterpretasikan bahwa nilai koefisien konstanta adalah 26,000 bernilai positif, artinya ketika perusahaan meningkatkan lingkungan kerja maka kinerja karyawan akan meningkat. Nilai koefisien lingkungan kerja adalah 0,381 bersifat positif yang artinya setiap peningkatan lingkungan kerja maka akan meningkatkan pula kinerja karyawan. 


\begin{tabular}{|c|c|c|c|c|c|c|}
\hline \multicolumn{7}{|c|}{ Coefficients $^{\mathrm{a}}$} \\
\hline \multicolumn{4}{|c|}{ Model } & \multirow{2}{*}{$\begin{array}{c}\text { Standardized } \\
\text { Coefficients } \\
\text { Beta } \\
\end{array}$} & \multirow{2}{*}{$\begin{array}{l}\mathrm{t} \\
3,511\end{array}$} & \multirow{2}{*}{$\begin{array}{l}\text { Sig. } \\
0,001\end{array}$} \\
\hline 1 & (Constant) & 19,332 & 5,507 & & & \\
\hline & $\begin{array}{l}\text { Disiplin Kerja } \\
\text { (X2) }\end{array}$ & 0,535 & 0,135 & 0,477 & 3,952 & 0,000 \\
\hline
\end{tabular}

a. Dependent Variable: Kinerja Kerja (Y)

Tabel 11. Hasil uji regresi sederhana disiplin kerja (X2) terhadap kinerja karyawan (Y). Sumber: Hasil Olah Data SPSS V26

Berdasarkan tabel 11, hasil penghitungan ouput menunjukkan bahwa koefisien dari persamaan regresi dapat diinterpretasikan; nilai koefisien konstanta adalah 19,332 bernilai positif, yang artinya ketika perusahaan meningkatkan disiplin kerja maka kinerja karyawan pada perusahaan juga meningkat. Nilai koefisien disiplin kerja 0,535 bersifat positif yang artinya setiap peningkatan disiplin kerja maka akan meningkat pula kinerja karyawan di perusahaan.

Analisis regresi berganda digunakan untuk mengukur pengaruh antara lebih dari satu variabel prediktor (variabel bebas) terhadap variabel terkait.

\begin{tabular}{|c|c|c|c|c|c|c|}
\hline \multicolumn{7}{|c|}{ Coefficients $^{\mathrm{a}}$} \\
\hline \multicolumn{4}{|c|}{ Model } & \multirow{2}{*}{$\begin{array}{c}\text { Standardized } \\
\text { Coefficients } \\
\text { Beta } \\
\end{array}$} & $\mathrm{t}$ & Sig. \\
\hline 1 & (Constant) & 15,122 & 5,681 & & 2,662 & 0,010 \\
\hline & Lingkungan Kerja (X1) & 0,245 & 0,114 & 0,277 & 2,141 & 0,037 \\
\hline & Disiplin Kerja (X2) & 0,401 & 0,145 & 0,358 & 2,761 & 0,008 \\
\hline
\end{tabular}

a. Dependent Variable: Kinerja Kerja (Y)

Tabel 12. Hasil uji regresi berganda lingkungan kerja (X1) disiplin kerja (X2) terhadap kinerja karyawan (Y). Sumber: Hasil Olah Data SPSS V26

Berdasarkan tabel 12, hasil penghitungan output menunjukkan bahwa koefisien hasil dari persamaan regresi dapat diinterpretasikan bahwa nilai koefisien konstanta adalah 15,122 bernilai positif, yang artinya ketika perusahaan meningkatkan lingkungan kerja dan disiplin kerja maka kinerja karyawan akan meningkat.

\section{Uji Koefisien Determinasi $\left(\mathbf{R}^{2}\right)$}

Uji koefisien determinasi digunakan untuk mengetahui sampai seberapa besar persentase variasi variabel bebas pada model dapat
Nilai koefisien lingkungan kerja adalah 0,245 bersifat positif yang artinya setiap peningkatan lingkungan kerja, maka akan meningkat pula kinerja karyawan di perusahaan. Nilai koefisien disiplin kerja adalah 0,401 bersifat positif, yang artinya setiap peningkatan disiplin kerja, maka akan meningkat pula kinerja karyawan.

diterangkan oleh variabel terkait baik secara parsial.

\begin{tabular}{|ll|r|r|r|}
\hline \multicolumn{4}{|c|}{ Model Summary } \\
Model & R & R Square & R Square & $\begin{array}{c}\text { Adjusted Error of } \\
\text { the Estimate }\end{array}$ \\
\hline 1 & $.431^{\mathrm{a}}$ & 0,186 & 0,171 & 3,923 \\
\hline
\end{tabular}

a. Predictors: (Constant), Lingkungan Kerja (X1) 


\section{Tabel 13. Hasil uji koefisien determinasi lingkungan kerja (X1) terhadap kinerja karyawan (Y). Sumber: Hasil Olah Data SPSS V26}

Berdasarkan tabel 13, besarnya nilai korelasi (R) sebesar 0,431. Dari output tersebut diperoleh $\mathrm{R}$ Square $\left(\mathrm{R}^{2}\right)$ sebesar 0,186 yang mengandung pengertian bahwa pengaruh lingkungan kerja (X1) terhadap kinerja karyawan (Y) sebesar 18,6 persen, sisanya 81,4 persen dipengaruhi oleh faktor lainnya.

\begin{tabular}{|ll|r|r|r|}
\hline \multicolumn{4}{|c|}{ Model Summary } \\
Model & R & R Square & R Square & $\begin{array}{l}\text { Adjusted Error of } \\
\text { the Estimate }\end{array}$ \\
\hline 1 & $.477^{\mathrm{a}}$ & 0,228 & 0,213 & 3,821 \\
\hline
\end{tabular}

a. Predictors: (Constant), Disiplin Kerja (X2)

Tabel 14. Hasil uji koefisien determinasi disiplin kerja (X2) terhadap kinerja karyawan (Y). Sumber: Hasil Olah Data SPSS V26

Dari tabel 14 menjelaskan besarnya nilai korelasi (R) sebesar 0,477. Dari output tersebut diperoleh koefisien determinasi $\left(\mathrm{R}^{2}\right)$ sebesar 0,228 yang mengandung pengertian, bahwa pengaruh disiplin kerja (X2) terhadap kinerja karyawan (Y) sebesar 22,8 persen, sedangkan sisanya 77,2 persen dipengaruhi faktor lain.

\begin{tabular}{|lc|r|r|r|}
\hline \multicolumn{4}{|c|}{ Model Summary } \\
Model & $R$ & R Square & $\begin{array}{c}\text { Adjusted } \\
\text { R Square }\end{array}$ & $\begin{array}{c}\text { Std. Error of the } \\
\text { Estimate }\end{array}$ \\
\hline 1 & $.539^{\mathrm{a}}$ & 0,290 & 0,263 & 3,698 \\
\hline
\end{tabular}

a. Predictors: (Constant), Disiplin Kerja (X2), Lingkungan Kerja

b. Dependent Variable: Kinerja Kerja $(\mathrm{Y})$

Tabel 15. Hasil uji koefisien determinasi lingkungan kerja (X1) disiplin kerja (X2) terhadap kinerja karyawan (Y). Sumber: Hasil Olah Data SPSS V26

Dari tabel 15 di atas, menjelaskan besarnya nilai korelasi (R) sebesar 0,539. Dari output tersebut diperoleh koefisien determinasi $\left(\mathrm{R}^{2}\right)$ sebesar 0,290 yang mengandung pengertian bahwa pengaruh lingkungan kerja (X1) dan disiplin kerja (X2) terhadap kinerja karyawan (Y) sebesar 29 persen, sedangkan sisanya 71 persen dipengaruhi faktor lain.

\section{Uji Signifikan (t)}

Uji signifikan $(t)$ pada dasarnya digunakan untuk mengetahui tingkat signifikan koefisien regresi. Jika suatu koefisien regresi signifikan menunjukkan seberapa jauh pengaruh suatu variabel independen dalam menerangkan variabel dependen. 


\begin{tabular}{|llr|r|r|r|r|}
\hline \multicolumn{7}{|c|}{ Coefficients $^{\text {a }}$} \\
Model & \multicolumn{2}{|c|}{$\begin{array}{c}\text { Standardized } \\
\text { Coefficients } \\
\text { Beta }\end{array}$} & $\mathrm{t}$ & Sig. \\
\hline 1 & $\begin{array}{l}\text { (Constant) } \\
\text { Lingkungan } \\
\text { Kerja (X1) }\end{array}$ & 0,381 & 0,110 & 0,431 & 3,482 & 0,001 \\
\hline
\end{tabular}

a. Dependent Variable: Kinerja Kerja (Y)

Tabel 16. Hasil uji t ingkungan kerja (X1) terhadap kinerja karyawan (Y).

Sumber: Hasil Olah Data SPSS V26

Berdasarkan tabel 16, nilai sig. lingkungan kerja (X1) sebesar 0,0001 <0,05, maka dapat disimpulkan bahwa pada hipotesis (H1) diterima, artinya terdapat pengaruh yang signifikan antara lingkungan kerja dengan kinerja karyawan. Nilai t-hitung variabel lingkungan kerja sebesar 3,482 > 2,006 t-tabel $(\mathrm{a} / 2$ : n-2), maka dapat dilihat bahwa lingkungan kerja mempunyai pengaruh positif terhadap kinerja karyawan (Hal diterima).

\begin{tabular}{|llr|r|r|r|r|}
\hline \multicolumn{7}{|c|}{ Coefficients $^{\mathbf{a}}$} \\
Model & \multicolumn{2}{|c|}{$\begin{array}{c}\text { Standardized } \\
\text { Coefficients } \\
\text { Beta }\end{array}$} & $\mathrm{t}$ & Sig. \\
\hline $1 \quad$ & $\begin{array}{l}\text { (Constant) } \\
\text { Disiplin Kerja } \\
\text { (X2) }\end{array}$ & 0,535 & 0,135 & 0,477 & 3,952 & 0,000 \\
\hline
\end{tabular}

a. Dependent Variable: Kinerja Kerja (Y)

Tabel 17. Hasil uji t disiplin kerja (X2) terhadap kinerja karyawan (Y).

Sumber: Hasil Olah Data SPSS V26

Berdasarkan tabel 17 , nilai sig. pada variabel disiplin kerja (X2) sebesar $0,000<$ 0,05 , maka dapat disimpulkan bahwa pada hipotesis dua (H2) diterima, artinya terjadi pengaruh yang signifikan antara disiplin kerja

\section{Uji Simultan (F)}

Uji simultan digunakan untuk melihat bagaimana variabel bebas secara bersama-sama memengaruhi variabel terkait. Apabila nilai F- terhadap kinerja karyawan. Pada nilai t-hitung variabel disiplin kerja sebesar 3,952>2,006 ttabel $(\mathrm{a} / 2: \mathrm{n}-2)$, maka dapat dilihat bahwa disiplin kerja mempunyai pengaruh positif terhadap kinerja karyawan (Ha2 diterima).

hitung > F-tabel maka hipotesis alternatif yang dinyatakan bahwa semua variabel independen berpengaruh signifikan terhadap variabel dependen.

\begin{tabular}{|c|c|c|c|c|c|c|}
\hline \multicolumn{7}{|c|}{ ANOVA $^{a}$} \\
\hline & & $\begin{array}{l}\text { Sum of } \\
\text { Squares }\end{array}$ & df & Mean Square & $\mathrm{F}$ & Sig. \\
\hline 1 & Regression & 290,783 & 2 & 145,392 & 10,630 & $.000^{\mathrm{b}}$ \\
\hline & Residual & 711,217 & 52 & 13,677 & & \\
\hline & Total & $1.002,000$ & 54 & & & \\
\hline
\end{tabular}

a. Dependent Variable: Kinerja Kerja (Y)

b. Predictors: (Constant), Lingkungan Kerja (X1), Disiplin Kerja (X2) 
Berdasarkan tabel 18, nilai sig. dari tabel hasil pengujian uji $\mathrm{F}$, diketahui nilai sig. sebesar $0,000<0,05$ maka sesuai dengan dasar pengambilan keputusan dalam uji $\mathrm{F}$, dapat disimpulkan bahwa hipotesis diterima atau dengan kata lain, bahwa lingkungan kerja (X1) dan disiplin kerja (X2) secara simultan berpengaruh terhadap kinerja karyawan (Y). Berdasarkan nilai F-hitung sebesar 10,630 > 3,17 (F-tabel) dengan ketentuan $\mathrm{df}_{1}=(\mathrm{k}-1)$ maka diperoleh (3-1) $=2, \mathrm{df}_{2}=\mathrm{n}-\mathrm{df}_{1}$ maka diperoleh $(55-2)=53$, sehingga F-tabel $=3,17$. Dengan demikian Ho3 ditolak dan $\mathrm{Ha} 3$ diterima. Hal ini disimpulkan bahwa hipotesis terbukti, atau dengan kata lain bahwa lingkungan kerja (X1) dan disiplin kerja (X2) secara simultan berpengaruh terhadap kinerja karyawan.

\section{KESIMPULAN}

Berdasarkan hasil penelitian dan pembahasan, berikut kesimpulan yang diperoleh peneliti: 1). Bahwa lingkungkan kerja berpengaruh positif dan signifikan terhadap kinerja karyawan pada PT Resindo, Jakarta Selatan. 2). Disiplin kerja berpengaruh positif dan signifikan terhadak kinerja karyawan pada PT Resindo, Jakarta Selatan. 3). Lingkungan kerja dan disiplin kerja memiliki pengaruh secara simultan terhadap kinerja PT Resindo, Jakarta Selatan.

\section{DAFTAR PUSTAKA}

Ardana. (2012). Manajemen Sumber Daya Manusia. Yogyakarta: Graha Ilmu.

Arikunto, S. (2011). Prosedur Penelitian: Suatu Pendekatan Praktik Edisi Revisi. Jakarta: Rineka Cipta.

As'ad, M. (2011). Psikologi Industri. Yogyakarta: Galia.

Bernardin, J. H., \& Russel, E. J. (2013). Human resource management (Sixth Edition). New York: Mc Graw Hill.

Darmadi. (2020). Pengaruh Lingkungan Kerja dan Disiplin Kerja Terhadap Kinerja Karyawan Pada Indomaret Cabang Kelapa Dua Gading Serpong Kabupaten Tangerang. Jurnal Ilmiah Manajemen Forkama, 3(3), 240-247.

Ferawati, A. (2017). Pengaruh Lingkungan Kerja dan Disiplin Kerja Terhadap Kinerja Karyawan Pada PT Cahaya
Indo Persada. Jurnal Manajemen Bisnis, 5 (1), 1-3.

Gozali, S. (2010). Manajemen Sumber Daya Manusia (Human Resources Management) Cetakan Kedua. Jakarta: Djambatan.

Hariwijaya, M. (2017). Metodologi dan Teknik Penulisan Skripsi, Tesis, Desertasi. Yogyakarta: Elmatera Publishing.

Hasibuan, M. (2013). Manajemen Sumber Daya Manusia. Edisi Revisi. Jakarta: Bumi Aksara.

(2017). Manajemen Sumber Daya Manusia. Jakarta: Bumi Aksara.

Kasmir. (2016). Manajemen Sumber Daya Manusia (Teori dan Praktik). Depok: Raja Grafindo Persada.

Liyas, J. N., \& Primadi, R. (2017). Pengaruh Disiplin Kerja Terhadap Kinerja Karyawan Pada Bank Perkerediatan Rakyat. Jurnal embaga Keuangan dan Perbankan, 2 (1), 18-26.

Malau, M. K., \& Wasiman. (2020). Pengaruh Disiplin Kerja dan Lingkungan Kerja Terhaap Kinerja Karyawan Pada PT. Sansyu Precision Batam. Jurnal Rekaman, 4(2), 487-498.

Mangkunegara, A. A. (2017). Manajemen Sumber Daya Manusia Perusahaan. Bandung: Remaja Rosdakarya.

Nisa, A., Kumroni, M., \& AR, H. (2017). Pengaruh Motivasi, Disiplin dan Lingkungan Kerja Terhadap Kinerja Karyawan Pada PT Pertamina Marketing Operation Region II Palembang. Jurnal Ilmiah TEKNO, 14 (1), 11-25.

Nitisemito, A. S. (2013). Manajemen Personalia (Manjemen Sumber Daya Manusia) cetakan VIII. Jakarta: Ghalia Indonesia.

(2014). Manajemen Personalia. Jakarta: Ghalia Indonesia.

Notoatmojo. (2012). Pendidikan Dan Perilaku Kesehatan. Jakarta: Rineka Cipta.

Permadi, I. (2017). Pengaruh Lingkungan Kerja dan Disiplin Kerja Terhadap Kinerja Pada CV Alam Hijau Sukabumi. Junal Ekonomi, 3(1), 24-31.

Prasetiya, L. (2016). Pengaruh Lingkungan Kerja dan Disiplin Kerja Terhadap Kinerja Karyawan pada PT Varia Usaha Beton Gresik. Jurnal Manajemen, 4(2), 255-266.

Putri, S. H. (2020). Pengaruh Disiplin Kerja dan Lingkungan Kerja Terhadap Kinerja 
Karyawan Pada Hotel Mndeline Bengkulu. Jurnal Manajemen Modal Insani dan Bisnis, 1 (1), 26-39.

Rivai, V. (2013). Mananjemen Sumber Daya Manusia untuk Perusahaan Dari Teori Ke Praktek. Bandung: PT. Raja Grafindo Persada.

(2014). Mananjemen Sumber Daya Manusia untuk Perusahaan Edisi ke 6. Depok: PT. Raja Grafindo Persada.

Santosa, B. P., \& Ashari. (2005). Analisis Statistik dengan Microsoft Excel. Yogyakarta: Andi Offset.

Sedarmayanti. (2017). MSDM Reformasi Birokrasi dan Manajemen Pegawai Negeri Sipil. Bandung: Refika Aditama.

Sekaran, U., \& Bougie, R. (2017). Metode Penelitian Untuk Bisnis Pendekatan Pengembangan-Keahlian. Jakarta: Salemba Empat.

Soetjipto, B. (2010). MSDM: Sebuah Tinjauan Komprehensif (Bagian I) Paradigma
Baru MSDM. Yogyakarta: Amara Books.

Sugiyono. (2011). Metode Penelitian Kuantitatif, Kualitatif dan $R \& D$. Bandung: Alfabeta. (2017). Metode Penlitian Administrasi. Bandung: Alfabeta.

Suprihatiningrum, J. (2012). Strategi Pembelajaran. Yogyakarta: A-Ruzz Media.

Yudinisih, N. D., Yudiatmaja, F., \& Yulianthini, N. (2016). Pengaruh Lingkungan Kerja dan Disiplin Kerja Terhadap Kinerja Pegawai pada Distanak Kabupaten Buleleng. Jurnal Manajemen, 4(1), 17.

Yulizar. (2019). Pengaruh Lingkungan dan Disiplin Kerja Terhadap Kinerja Perawat Pada Rumah Sakit Umum Daerah Bangkinang. Jurnal Ensiklopedia Social Review, 1(2), 145149 